\title{
Factors affecting the exit from farming of young farmers in Turkey: the case of Niğde province
}

\author{
Ali Berk ${ }^{1}$ \\ ${ }^{1}$ Ministry of Agriculture and Forestry, General Directorate of Agriculture Reform, Ankara, Turkey. E-mail: berk_ali@hotmail.com. \\ ${ }^{*}$ Corresponding author.
}

\begin{abstract}
This study has focused on the factor affecting the exit from farming of young farmers, since it is an important issue in many provinces of Turkey. Data obtained through face-to-face interview method with 85 selected young farmers (aged 15-40 years) engaged in agricultural activity in the Niğde province in 2017. Logistic regression model based upon the dependent variable decision to exit from farming was used to determine relevant factors. According to results, number of children, the presence of house in the city center and the monthly income level has effects to exit from farming. Young farmers have priorities to reach a better life conditions for their children such as better education and health care services. Rural investment support should be increased; entrepreneurship and innovation trainings should be expanded by encouraging training on agriculture. It would be beneficial to develop different applications such as distance learning modules and digital agriculture.
\end{abstract}

Key words: rural, agriculture, exit from farming, young farmers.

Fatores que afetam a saída de jovens agricultores de propriedades rurais na Turquia: o caso da província de Niğde

RESUMO: Este estudo centrou-se no fator que afeta a saída da agricultura de jovens agricultores, uma vez que é uma questão importante em muitas províncias da Turquia. Dados obtidos através do método de entrevista presencial com 85 jovens agricultores selecionados (com idade entre 15 e 40 anos) envolvidos na atividade agrícola na província de Niğde em 2017. Modelo de regressão logística baseado na variável dependente decisão de sair da agricultura foi usado para determinar fatores relevantes. De acordo com os resultados, o número de crianças, a presença de casa no centro da cidade e o nível de renda mensal tem efeitos para sair da agricultura de jovens agricultores na província de Niğde. Os jovens agricultores têm prioridades para alcançar melhores condições de vida para seus filhos, como melhor educação e serviços de saúde. $O$ apoio a investimento rural deve ser aumentado e os treinamentos de empreendedorismo e inovação devem ser expandidos, incentivando a capacitação em agricultura. Com isso, seria benéfico desenvolver diferentes aplicações, como módulos de ensino à distância e agricultura digital.

Palavras-chave: rural, agricultura, saida da agricultura, jovens agricultores.

\section{INTRODUCTION}

The food and agriculture sectors are one of the most important areas affected by the rise of unemployment and youth unemployment. Besides those negative conditions in rural areas, farms face some problems such as demographic processes, reluctance of young people to take over farms and unwillingness of older managers to transfer those (COPUS et al., 2006). While fertility rate has fallen below the regeneration rate in rural areas where young and productive population has been lost by migration, a rapid increase in the proportion of ageing population is observed and these areas may soon face in danger of total discharge. These areas, which eventually lost their continuity in production, can also be affected by land use and migration in agricultural structures for nearly future.

Factors affecting structural change (that is exit, entry, and firm composition) in farming include many dimensions (BOEHLJE, 1992). Boehlje discuses that 5 different groups of factors influence change in the structure of farming: technology, human capital, finances, institutions, and sociology. Results of a study by BRAGG \& DALTON (2004), four variables were revealed that significantly influence the exit decision. Older producers, higher off-farm income, lower returns over variable cost, and greater diversification of farm income were more likely associated with a decision to leave dairy 
farming (BRAG \& DALTON, 2004). According to the European Commission, people are leaving their places where they live for various reasons such as economic, social, political, demographic and environmental influences (BARILLA, 2017). That's why; the programmes and instruments aiming to encourage older farmers to hand over their agricultural holdings or exit from farming (the early retirement programme) were implemented in many EU Member States (EC, 2013).

The high rates become a social problem in the world. The economic contraction, which is one of these problems, affects many countries in the world, and the labor market is negatively affected by these developments (ÖZ, 2010). Thus, most governments give direct payments to young people for entering farming for setting up a business and an increased rate. Actually there are many dimension of this issue. Alternative policies can be developed as younger farmers are working on farms whilst the older generation remains the official head of the holding (WILLIAMS, 2015).

In the last years, global economic crisis in many countries has negative effects on unemployment. According to OECD statistics, the unemployment rate is $5.5 \%$ in OECD countries, $7.3 \%$ in EU-28, $20.9 \%$ in Greece, $16.6 \%$ in Spain, $10.8 \%$ in Spain, $10.1 \%$ in Turkey and $4.1 \%$ in the US, respectively. Nevertheless, parallel to the increase in unemployment rates, the significant rise in youth unemployment rates reveals that young people have significant problems in terms of employment participation. On a global scale, while the youth unemployment rate of $11.9 \%$, this ratio is $16 \%$ in EU-28, $12.1 \%$ in Estonia, 34.8\% in Italy, 38.7\% in Spain, $17.9 \%$ in Sweden and $20.6 \%$ in Turkey (OECD, 2018). The fact that young unemployment is on the rise has important consequences in terms of economic, political and social consequences. In developing countries, $20 \%$ of population consists of young people and they have a great potential resource for their countries. But generally, those countries do not benefit from this source in rural areas efficiently. As a result of which this situation, young generations leave the rural areas and rural societies are getting older. That causes many problems in the rural areas such as sustainability issue of food and agricultural production for whole country.

Turkey, as a developing country, faces the similar problems in terms of changes in rural population in rural areas. Rural population shows a rapid declining trend in recent years. In addition, while the rural population in Turkey is mostly composed of young people in early days, now, this population has a higher ability to increase. Today; however, the natural increase in the rural population is reduced. Therefore, it can be predicted that rural population in our country will continue to decline in the following years (YILMAZ, 2015). The share of the total population of the rural population in Turkey in 1990 was $41 \%$, while in 2012 and $25 \%$ in 2008 to $35.1 \%$ in 2000 dropped to $22.7 \%$. On the other hand, according to the statistics, the share of rural population in the total population in 2015 has decreased to $7.9 \%$ due to the administrative division changes. Agricultural labor force in Turkey who lives in rural areas is approximately 5.5 million. When we look closely to the distribution of employment by age group, 49\% are in the 15-39 groups and it is seen that the young population has an important place in agriculture sector. According to the statistics of the Ministry of Food, Agriculture and Livestock, the number of farmers aged 18-40 years registered in the Farmer Registration System (FRS) is 330,412, accounting for $13.46 \%$ of the total registered farmers (TÜİK, 2018).

There are many scientific researches on changes in population in rural areas especially on migration from rural to urban or reasons of leaving the agricultural activities. In a study by ZIRHLIOĞLU (2010) indicated that the most important factor the affecting the domestic migration in agricultural activities in Van province of Turkey was unemployment. YALÇIN \& KARA (2016) reported that because of income inefficiency, farmers tend to leave to rural areas. In the study of AYDIN CAN \& ENGINDENIZ (2017); they indicated that the lack of job opportunities in rural areas and inadequate income in the agricultural sector also lead to poverty and poverty must be reduced in order to reduce unemployment.

Several special programs for young farmers in Turkey is being developed in order to decrease the perception of migration in rural areas and to ensure sustainability in agricultural production. In this context, special support programs were launched in order to support entrepreneurship of young farmers, to increase the income level, to create alternative income resources, to contribute to rural employment of young population in rural intended for young farmers in Turkey. The most important one is "Supporting Programs for Young Farmers under the Rural Development Supports". Within this scope, it is targeted to grant 48.100 young farmers with 1.443.000.000 TL grant in 2016-2018 period. On the other hand, Turkey, as a candidate 
country, has prepared IPARD Programme in order to benefit the Component V (Rural Development) of IPA (Instrument for Pre-Accession Assistance). This Programme was approved by the European Commission on February 25, 2008, which contains several positive discriminations towards young farmers (IPARD, 2018).

This study aimed to determine the factor affecting the exit from farming of young farmers in Niğde province. For this reason, in the first part, the socioeconomic characteristics, internet and social media usage levels of young farmers operating in the agriculture sector in Niğde province were determined. And then, in the second part, the method of econometric analysis applied for data is explained. In the third part, research findings including descriptive statistics were investigated, and in the fourth part, the conclusion and recommendations are given.

\section{MATERIALS AND METHODS}

The main material of the study consisted of data obtained by face-to-face interview method with 85 selected young farmers (aged 15-40 years) engaged in agricultural activity in the Niğde province in 2017. In this study, the study field was chosen as a purposeful, and the number of samples was determined using simple random methods. Numerous secondary data and various scientific studies have also been used. There are several definitions for the concept of "young". For example, in developing countries, young people (defined by the United Nations as those aged 15 to 24) make up 20 per cent of the population on average (LUNDIUS, 2011). But the age group in this study was selected as $15-40$ ages group in order to harmonize with Ministry of Food, Agriculture and Livestock supports criteria.

The agriculture is the main source of income for the people of the region. Niğde province is among the top 10 producer provinces in Turkey while it is the biggest apple producers in Turkey approximately with $6,204,476$ apple trees, other important agricultural products are white cabbage and potato.

Niğde province is a province in the southern part of Central Anatolia (Figure 1). The population decreased from 348.081 to 340.270 in $2000-2018$ periods which are equal to $0.45 \%$ share in the total

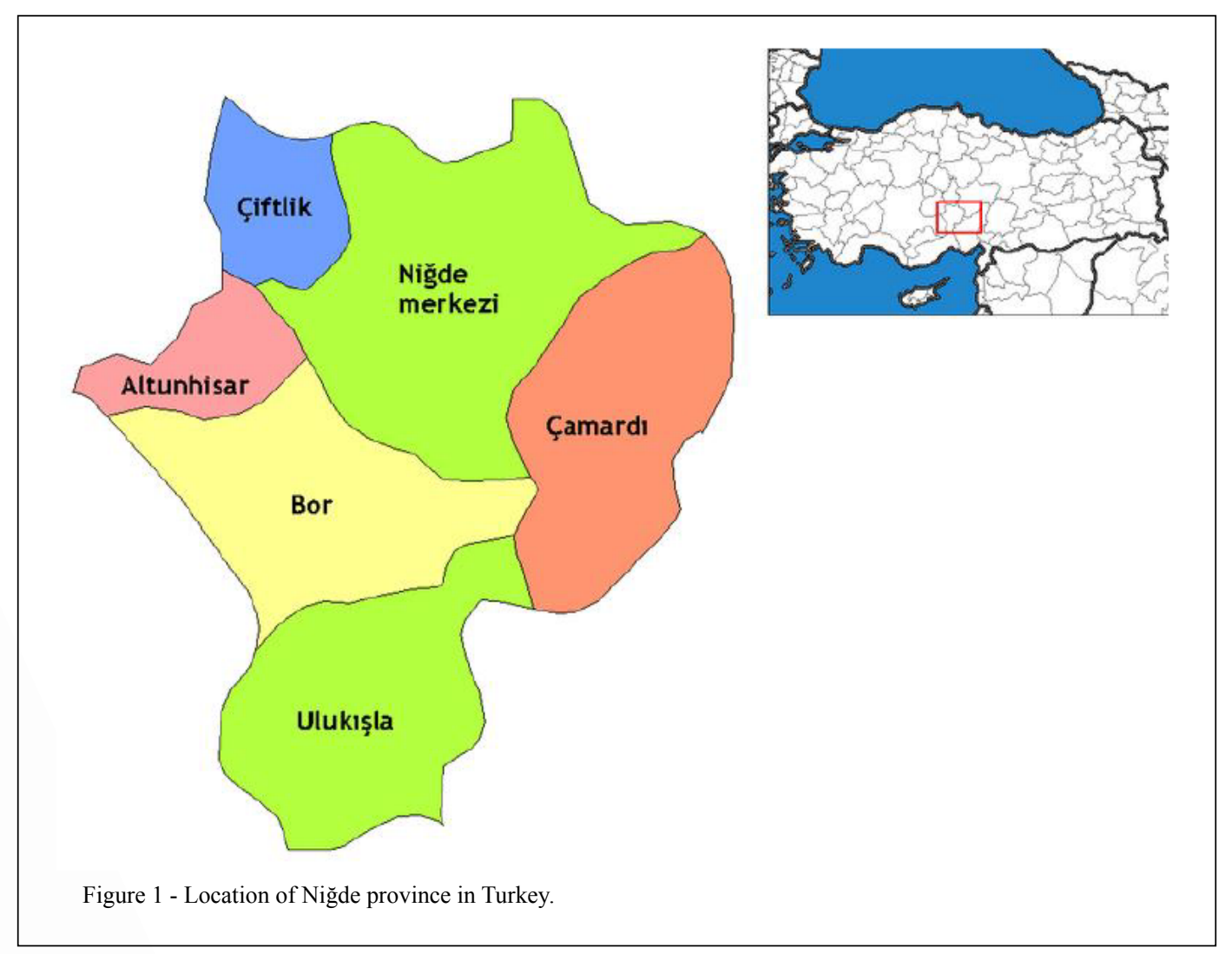

Ciência Rural, v.48, n.8, 2018. 
population of Turkey in 2018. In addition, one of the reasons for the selection as a research area is that the decrease in population will continue on the base and the population will decrease by $1.8 \%$ in the period of 2012 2023 according to the population projections (TÜIK, 2018). According to official registration, 15.168 persons engage in farming activities equal to $0.7 \%$ of farmers in Turkey. However, $17 \%$ (2.582) of the farmers in the province are young farmers (MFAL, 2018).

In this study, Proportional Sampling Method has been used as the research is directed towards a specific target group. According to statistics, the number of total farmers in Niğde province is 15.168 and the number of young farmers in Niğde province is $17 \%$. The samples size was calculated as 85 in $8 \%$ error margin and $95 \%$ confidence interval. Formula of method can be shown as below:

$$
n=\frac{N x p x q}{(N-1) x \sigma_{P_{x}}^{2}+p x q}
$$

$\mathrm{q}=\mathrm{p}-1$

$$
\sigma_{P_{x}}^{2}=\left(\frac{r}{Z_{\propto / 2}}\right)^{2}
$$

$\mathrm{N}=$ Population size

$$
\mathrm{n}=\text { Sample size }
$$

$\mathrm{p}=$ Probability of success on any one trial

$\mathrm{q}=$ Probability of failure on any one trial

$\sigma=$ Standard deviatio $\sigma \mathrm{n}$

$r=$ Linear correlation coefficient of a sample

$Z=Z$ score (AKSOY \& YAVUZ, 2012; MIRAN, 2007).

In this study, Logistic Regression (Binary) method was used in order to determine the factor affecting the exit from farming of young farmers in agriculture sector of Niğde province.

Logistic regression is the proper regression analysis to conduct when the dependent variable is dichotomous (binary). In general, the logistic regression model is written mathematically for $p$ number of variables as follows.

$L=\ln \left(\frac{P}{1-P}\right)=\beta_{0}+\beta_{1} X_{1}+\beta_{2} X_{2}+\ldots . .+\beta_{p} X_{p}$

(ALBAYRAK et al. 2005) (Eq.2)

Since the parameters of the Logistic Regression model cannot be obtained analytically, they are estimated by an iterative method (Maximum Likelihood-ML). Even though there is a linear relationship between dependent variable of model and independent variables, the relationship between the probabilities and dependent variables is not linear. Probability values according to given properties of independent variables which it means probability of occurrence of an event calculated by:

$$
P i=\frac{1}{1+e^{-\left(\beta 0+\beta_{1} X_{1}\right)}}
$$

$\mathrm{P}$ : probability of $\mathrm{i}$ occurring

(Albayrak et al. 2005) (Eq.3)

e: natural logarithm base $(=2,718)$

$\beta_{0}$ : Interception at $y$-axis

$\beta_{1}$ : line gradient

$X_{1}$ predicts the probability of $i$

In the study, binary logistic regression analysis was used in order to determine the factor affecting the exit from farming of young farmers in agriculture sector of Niğde province.

\section{RESULTS AND DISCUSSION}

In this study, the socioeconomic characteristics, marital status, education level, residence status, income level, farm sizes and internet and social media usage of young farmers was investigated. The level of undergraduate can be positively or negatively linked to the probability of the exit decision of young farmers by creating the opportunity to access off-farm employment to adopt management intensive systems. When the summary statistics of the variables on young farmers' profile is examined, $92.7 \%$ of the interviewed young farmers were men and $7.3 \%$ of were women. When we looked at survey results of marital status of young farmers living in rural areas, 59.3\% were married while $40.7 \%$ were single. However, $57.3 \%$ of young farmers have children and $41.5 \%$ of them do not have children. When the education level of young farmers is examined, it is determined that $33.3 \%$ of them had primary education and $45.3 \%$ had secondary education. The rate of undergraduate was reported as $21.4 \%$ as table 1 .

When the descriptive statistics were analyzed, the place of residence of young farmers shows that $57.6 \%$ of young farmers live in the village and $30.6 \%$ of them live in the district (Table 2). However, $4.7 \%$ of business owners reside in the city center.

There is a close relationship between the monthly income level of young farmers and agricultural production. When the income level of young people is examined, $76.9 \%$ of them have income of $2.000 \mathrm{TL}$ and below. Table 3 shows that the share of young farmer who has under the level of the minimum wage in Turkey (1.300 TL/month) and has less than $1.000 \mathrm{TL}$ income was of $39.1 \%$.

The average farm size of young farmers was 24.4 decares in property land, while it was 9.1 decares in rented land while average farm size 
Table 1 - Education level of young farmers.

\begin{tabular}{lccc}
\hline Education level & Frequency $(\mathrm{N})$ & Percentage (\%) & Cumulative frequency (\%) \\
\hline Primary education & 28 & 33.3 & 33.3 \\
Secondary education & 38 & 45.3 & 78.6 \\
Undergraduate & 18 & 21.4 & 100.0 \\
Total & 84 & 100.0 & - \\
\hline
\end{tabular}

for all agricultural farms is 33.5 decares (Table 4). Considering the average farm size in Turkey is approximately 61 decares, young farmers in the region have equal to half of lands in whole country. On the other hand, when asked whether land ownership is changed in Turkey or not in last 5 years, $13.3 \%$ of the them said "increased", 39.8\% of them said "decreased" while $47 \%$ of them said "not changed".

About internet usage, e-shopping and usage habits of social media shows that the share of young farmers who shops on the internet was $39.7 \%$ and partly shops were $6.4 \%$ (Table 5 ). In this context, it can be said that almost half of (46.1\%) young farmers shop online and $53.9 \%$ do not use the internet while shopping. However, the use of social media among young farmers seems to be at a higher level. While the share of young farmers using social media was $53.2 \%$, partly user was $68.8 \%$. The share of farmers who did not use social media was $31.2 \%$.

In the logistic regression used in this study, young farmers' continuation status to agricultural activity was chosen as a dependent variable. According to this, the dependent variable of young farmers who make plans to exit from agriculture is 1 , and to continue agriculture is assumed to be 0 .

The dependent variable for using the logistic regression should be binary (as 0-1), otherwise using a multiple regression is more appropriate. In terms of independent variables; a total of 16 independent variables (sex, age, marital status, family size, having a child, numbers of children, education level, duration of experience in agriculture, non-agricultural occupation, having an own house, having a house in city center, income level, land value owned, opinion on new employment opportunities, having a certificate, opinion on infrastructure of living place) in logit models, both numerical and non-numerical variables were used. Here, different model trials were implemented with numerical variables besides categorical variables. However, these models were not preferred because both the Cox \& Snell $\mathrm{R}^{2}$ and Nagelkerke $\mathrm{R}^{2}$ values were low and the numerical variables were not statistically significant. Therefore, the analysis results included numeric variables (number of children) containing these numerical values.

According to results of analyze, the factors affecting the farmers' decision on exit from farming activity in Niğde province were determined as gender, marital status, farm size, ownership of children and its number, education, experience, nonagricultural activities, ownership of their own house, presence of home in the city center, income level, change in land ownership, certificate ownership, new employment opportunities and infrastructure status. The explanations for the variables used in the analysis are given in table 6 .

Since chi square statistic value is a good criterion for the goodness of fit of the general model and corresponds to the F statistic used in Regression Analysis. It was shown the Chi-square test results here.

Table 2 - Place of residence of young farmers.

\begin{tabular}{lccc}
\hline Place of residence & Frequency $(\mathrm{N})$ & Percentage (\%) & Cumulative frequency (\%) \\
\hline Village & 49 & 57.6 & 57.6 \\
District & 26 & 30.6 & 88.2 \\
Village + District & 6 & 7.1 & 95.3 \\
City center & 4 & 4.7 & 100.0 \\
Total & 85 & 100.0 & - \\
\hline
\end{tabular}

Ciência Rural, v.48, n.8, 2018. 
Table 3 - Monthly income level of young farmers.

\begin{tabular}{lccc}
\hline Income Group (TL) & Frequency $(\mathrm{N})$ & Percentage (\%) & Cumulative frequency (\%) \\
\hline $0-1000$ & 32 & 39.1 & 39.1 \\
$1001-2000$ & 31 & 37.8 & 76.9 \\
$2001-5000$ & 17 & 20.7 & 97.6 \\
$5000+$ & 2 & 2.4 & 100.0 \\
Total & 82 & 100.0 & - \\
\hline
\end{tabular}

In applying Chi-square test, it was found 3,626 that was statistically significant $(p<0.05)$. This is an indication of the model's goodness of fit.

However, the Loglikehood (-2LL) value corresponding to $\mathrm{R}^{2}$ in the multiple regression is 35.503, while the Cox \& Snell $\mathrm{R}^{2}$ value is 0.387 and the Nagelkerke $\mathrm{R}^{2}$ value is 0.517 .

As a result of survey, it was determined that the number of children owned by young farmers, the presence of home in the city center, and the monthly income level are the most influential variables on the likelihood of continuing farming activities of young farmers. Among these variables, presence of home in city center at $1 \%$ level, number of children at 5\% and monthly income level at $10 \%$ was statistically significant (Table 7). The model reported 3 variables that were significant in determining the decision to exit farming: number children, presence of home in city, and income level.

In the Logit model, the marginal effects are calculated below by taking into account the averages of the independent variables included in the analysis so that coefficient interpretations can be made.

$\mathrm{Z}=-3.365+1.126 * \mathrm{NC}+3.312 * \mathrm{PHC}-2.469 * \mathrm{IL}$

The mean values are; NC: 2.49 ; PHC: 0.2375 and IL: 0.280 respectively. Accordingly, marginal effects;

$Z=-3.365+1.126 * 2.49+3.312 * 0.2375-2.469 * 0.280$

$\mathrm{Z}=-0.466 \quad \mathrm{e}^{-\mathrm{z}}=\mathrm{e}^{-(-0,466)}=1.593$

$\mathrm{f}(\mathrm{Z})=\mathrm{dp} / \mathrm{dZ}=\mathrm{e}^{-\mathrm{z}} /\left(1+\mathrm{e}^{-\mathrm{z}}\right)^{2}=1.593 /(1+1.593)^{2}=0.2369$

Table 4 - Average farm size of young farmers.

\begin{tabular}{lcc}
\hline Land ownership & $\begin{array}{c}\text { Average Farm Size } \\
\text { (decare) }\end{array}$ & $\begin{array}{c}\text { Percentage } \\
(\%)\end{array}$ \\
\hline Property land & 24.4 & 72.8 \\
Rented land & 9.1 & 27.2 \\
Total & 33.5 & 100.0 \\
\hline
\end{tabular}

In this case, the marginal effects and comments obtained when considering the averages; $\mathrm{f}(\mathrm{Z}) \beta_{\mathrm{i}}=0.2369 * 3.312=0.7846$; as the number of young farmers increases in the presence of home in city center, the probability of exiting farming increases by $78.5 \%$.

$f(Z) \beta_{i}=0.2369 * 1.126=0.2668$; as the number of children in young farmers increases, the probability of exiting from farming increases by $26.7 \%$.

$\mathrm{f}(\mathrm{Z}) \beta_{\mathrm{i}}=0.2369 *(-2.469)=-0.5849$; the probability of exiting from farming decreases by $58.5 \%$ as the level of income increases in young farmers.

A statistically significant correlation were reported at $1 \%$ level between factor affecting on the exit from farming of young farmers and the presence of home in the city center. The increase in presence of home in the city center also increases the possibility of young farmers to exit farming. In this case, it can be said that the probability of young farmer's exit from farming will increase by $78.5 \%$ in case of an increase in the number of houses in the city center.

However, there is a statistically positive correlation at $5 \%$ level between the number of children with young farmers' attitudes to continue farming and the number of children they have. The increase in the number of children also increases the likelihood of young farmers to exit farming. In this case, the probability of the young farmers to exit farming would increase by $26.7 \%$ in case of one unit increase in this variable depending on the number of children.

On the other hand, the level of income is another significant variable. There is a negative correlation at $10 \%$ level between young farmers' attitudes to continue farming and the monthly income level. The increase in the income level also reduces the young farmers' attitudes to exit farming. In this case, it is also possible to say that the probability of young farmers' to exit farming will decrease by $58.5 \%$ in case of one unit increase in this variable depending on income level. 
Table 5 - Use of internet for shopping on the internet and social media use for young farmers.

\begin{tabular}{|c|c|c|c|c|}
\hline \multirow{2}{*}{ Response } & \multicolumn{2}{|c|}{--------------------Online Shopping------------------ } & \multicolumn{2}{|c|}{---------Social Media Use---------- } \\
\hline & Frequency $(\mathrm{N})$ & $\%$ & Frequency $(\mathrm{N})$ & $\%$ \\
\hline Yes & 31 & 39.7 & 41 & 53.2 \\
\hline No & 42 & 53.9 & 24 & 31.2 \\
\hline Partly & 5 & 6.4 & 12 & 15.6 \\
\hline Total & 78 & 100.0 & 77 & 100.0 \\
\hline
\end{tabular}

\section{CONCLUSION}

In this study, it was determined that the number of children, the presence of house in the city center and the monthly income level has effects to exit from farming of young farmers in Niğde province. This is because young farmers engaging with agricultural activities and their families do not want their children to pursue the same profession. One of the most important o reasons is because of life conditions and low income level. Thirty nine percent of young farmers have lower monthly comparing o minimum wage level (1.000 TL) in Turkey.

In addition, young farmers have priorities to reach better life conditions for their children such as better education and health care services. In this context, it is necessary to meet basic priorities of young farmers and their families such as education and health in rural areas. In addition, increasing the roads in rural area, educational opportunities, social facilities, technology use and other possibilities will make rural areas more attractive for young farmers. In this respect, current agricultural support policies are insufficient and unstable, and besides, the scope and space of supports should be expanded.

Rural investment support, which provides positive discrimination to young farmers and improvements, should be implemented in the rural area such as housing support, financial support and consultancy support. Having a house in the city center needs to be encouraged.

On the other hand, economic factors also play a role in exiting from farming. In this context, if the level of income increases, tendency of remaining in the farming sector seems to increase. It would be beneficial for young farmers to work on diversified economic activities in the countryside by providing alternative income models such as agricultural insurance system and price insurance for agricultural products.

Entrepreneurship and innovation trainings should be expanded by encouraging training on agriculture in terms of young population and directed towards alternative income sources. In this context, it will be useful to inform the young farmers about the importance of agricultural products and to educate them about the cultivation and marketing of these products and to explain the branding issues such as geographical indicators.

Based on these results, it would be beneficial to develop different applications such as distance learning modules and digital agriculture. In addition, the social media usage rate was reported to be $68.8 \%$. This is an important criterion for young farmers to demonstrate their competence in using digital technologies.

Table 6 - Variables used in logistic regression analyses.

\begin{tabular}{|c|c|}
\hline Variables & Explanation \\
\hline Continuation Status to Farming Activity & $\begin{array}{l}\text { Y:1, Those who are planning to exit from farming activities } \\
\text { Y:0, Those who are not planning to exit from farming activities }\end{array}$ \\
\hline Numbers of Children & Refers to the numbers of children young farmers have \\
\hline Home Presence in the City Center & $\begin{array}{l}\text { Refers to home presence in city center of young farmers. } \\
\text { If Yes } 1 \text {; Not: } 0\end{array}$ \\
\hline Income Level & $\begin{array}{l}\text { Refers to income level of young farmers. If monthly income level is } 2000 \mathrm{TL} \text { and } \\
\text { over : } 1 \text {; Not: } 0\end{array}$ \\
\hline
\end{tabular}

Ciência Rural, v.48, n.8, 2018. 
Table 7 - The Estimates of logistic regression analysis for the status of farming activity of young farmers.

\begin{tabular}{lccccccc}
\hline Variables & B & S.E. & Wald & Sig. & \multicolumn{2}{c}{ Exp(B) } & -----95\% C.I. for EXP(B)----- \\
\hline Constant & -3.365 & 1.372 & 6.017 & $0.014^{*}$ & 0.035 & Lower & Upper \\
Number of Children (NC) & 1.126 & 0.491 & 5.262 & $0.022^{* *}$ & 3.083 & 1.178 & 8.066 \\
Presence of Home in City (PHC) & 3.312 & 1.285 & 6.646 & $0.010^{* * *}$ & 27.440 & 2.212 & 340.405 \\
Income Level (IL) & -2.469 & 1.492 & 2.739 & $0.098^{*}$ & 0.085 & 0.005 & 1.576 \\
\hline
\end{tabular}

${ }^{*} 0.10 ;{ }^{* *} 0.05$ and ${ }^{* * *} 0.01$ denote significant levels.

\section{ACKNOWLEDGEMENTS}

Author thanks to Ministry of Agriculture and Forest of Turkey for supports in data collecting period.

\section{CONFLICTS OF INTEREST}

The authors declare no conflict of interest. The founding sponsors had no role in the design of the study; in the collection, analyses, or interpretation of data; in the writing of the manuscript, and in the decision to publish the results.

\section{REFERENCES}

AKSOY, A.;YAVUZ, F., 2012. Analysis on the reasons for quitting sheep and goat rearing of farmers: a case of east anatolia region. Anadolu J Agr Sci, v.27, n.2, p.76-79, 2012. Available from: $<$ http://dergi.omu.edu.tr/index.php/ANAJAS/article/view/1966>. Accessed: April 11, 2018.

ALBAYRAK, A.S., et al. SPSS Uygulamalı Çok Değişkenli İstatistik Teknikleri. 426p. ISBN: 975-9091-14-3, Ankara, Turkey, 2005.

AYDIN CAN, B.; ENGINDENIZ, S. Employment problems of youth in rural area: a review on Turkey In: KOÇ, S., et al. Kayıt Dıșı İstihdam ve Ekonomi. p.94-102, 2017. Available from: $<$ https://www.researchgate.net/publication/321274277_Kirsal_ Kesimde_Genclerin_Istihdam_Sorunlari_Turkiye_Uzerine_Bir_Inceleme $>$. Accessed: January 21, 2018.

BARILLA, F. 2017. Food \& Migration. Understanding the geopolitical nexus in the Euro-Mediterranean. Available from: $<$ https://www.barillacfn.com/en/macrogeo/>. Accessed: January 21,2018

BOEHLJE, M.. Alternative models of structural change in agriculture and related industries. Agribusiness. v.8, p.219-231, 1992.

BRAGG, L.A., DALTON, T.J. Factors Affecting the Decision to Exit Dairy Farming: A Two-Stage Regression Analysis. J. Dairy Sci. v.87, p.3092-3098, 2004.

COPUS, A., et al. Study on employment in rural areas (SERA) Brussels: European Commission. 2006.
EC (EUROPEAN COMMISSION). Overview of CAP reform 2014-2020. Brussels: European Commission. 2013. Available from: $<$ https:/ec.europa.eu/agriculture/sites/agriculture/files/policyperspectives/policy-briefs/05_en.pdf $>$. Accessed: January 2, 2018.

IPARD. IPARD Programme. 2018. Available from: < http://www. ipard.gov.tr/prog-en>. Accessed: January 2, 2018.

LUNDIUS, R.V. Feeding future generations: Young rural people today - prosperous, productive farmers tomorrow. Proceedings of the Governing Council High-Level Panel and Side Events, IFAD publications, 2011.

MFAL. Farm Registry System Records. Ministry of Food Agriculture and Livestock, Ankara, Turkey, 2018.

MIRAN, B. Introduction to Statistics. 297p., Ege University: İzmir, Turkey, 2007.

OECD. Organisation for Economic Co-operation and Development. 2018. Available from: <https://data.oecd.org/ unemp/youth-unemployment-rate.htm>. Accessed: June 9, 2017.

ÖZ, S., Kriz ve İşsizlik: Başarı örnekleri ve çözüm önerileri. Working Paper Series: 1024. TÜSİAD-Koç University Economic Research Forum, Istanbul, Turkey, 2010. Available from: $<$ https://eaf.ku.edu.tr/ sites/eaf.ku.edu.tr/files/erf wp 1024.pdf > . Accessed: January 2, 2018.

TÜİK. Turkish Statistical Institute, Ankara, Turkey, 2018. Available from: $<$ http://www.turkstat.gov.tr/Start.do;jsessionid=Y CT6bDTNpyY3TfvNx2TTH13WGvyycvJxQHRTG8GYpRzmnQ nkcJ5z!1008365352>. Accessed: January 2, 2018.

YALÇIN, G.E; KARA, F.Ö. Kırsal Göç ve Tarımsal Üretime Etkileri. Harran Tarım ve Gıda Bilimleri Dergisi, v.20, n.2, p.154-158, 2016.

YILMAZ, M. Changes of Rural Population in Turkey and its Distribution By Provinces (1980-2012), Eastern Geographical Review; v.20, n.33, 2015.

ZIRHLIOĞLU, G. The Effects of Immigration on Van's Agriculture. YYU Tarım Bilimleri Dergisi, v.20, n.3, p.144-152, 2010 .

WILLIAMS, F. Barriers Facing New Entrants to Farming - an Emphasis on Policy. Land Economy Working Paper Series. SAC. London, England, 2015. 